\title{
Waiting for the Barbarians: Rare Books and the New University in Canada
}

Bruce Whiteman $^{+}$

Many of you, I am sure, will recognize in my rather rhetorical title the name of one of the best-known poems of Constantine Cavafy, the Greek poet born in Alexandria who haunts Lawrence Durrell's 'Alexandria Quartet' series of related novels. In his poem, Cavafy describes the residents of Rome patiently awaiting the arrival of the barbarians, whose coming is expected and seemingly inevitable. These barbarians are dazzled by beautiful silver and gold work, and are 'bored by rhetoric and public speaking,' a detail in the poem which ought perhaps to have given me pause, but did not. I will return to Cavafy's poem and the irony of its conclusion later in my remarks.

Our conference this week takes place during the fiftieth anniversary year of the Bibliographical Society of Canada, an organization which was founded by Lorne Pierce and his fellow bibliographers in I946. That is reason enough for all of us to celebrate; and as I am on the whole a mainly optimistic sort of person, I hesitate to inject a note of gloom into what deserves to be a high-spirited occasion. But for many reasons, some of them personal and some of them professional, I have been giving a good deal of thought recently to what it is that I - and many of you - do, and how the sort of collection I curate fits into the current culture of libraries and higher education which, as we know, is changing radically these days. What I see - at McGill, more generally in Quebec, and even more generally still in the rest of Canada - depresses me somewhat; and unless I have unwittingly entered on the male climacteric and am mistaking my own decline for the decline of the world of

+ Bruce Whiteman is the Librarian of the William Andrews Clark Memorial Library at UCLA. His previous position was Head of Rare Books and Special Collections at McGill University. Among his recent books are Lasting Impressions: A Short History of English Publishing in Quebec (1994) and J.E.H. MacDonald (1995). His paper was the key-note address delivered on ro June 1996 in Halifax at the banquet of the Annual General Meeting of the Bibliographical Society of Canada on the occasion of the Society's fiftieth anniversary. 
institutional rare book collections, I think that I have just cause to be depressed.

Those of us who work in long established collections are used to taking a long-term perspective on things. We know that in the history of any institution, whether a university or a library within a university, there are good times and bad times, times of plenty and times of dearth, times of idiocy and times of remarkable intellectual and cultural flowering. At another level we also know that instances of immense change in the past have been met usually by equally immense flexibility and intelligence by that most flexible and intelligent of all creatures, homo sapiens. The printing press replaced the copyist, the typewriter replaced the holograph, the linotype machine replaced the compositor, and so on; and whatever local resistance these changes produced died out and was subsumed into what we like to call progress, a word which Mary Russell Mitford with foresight called 'an expressive Americanism.' Knowing these things makes it less easy to be an accurate pessimist; and no one, of course, looks sillier in retrospect that an inaccurate pessimist.

So just what is it, you will be thinking, that I am depressed and pessimistic about? In a nutshell, it is this: first, that I see the generalized culture of librarianship turning its face from 'the book' in a spirit of aggressive anti-historicism and placing its faith, with an almost Gnostic intensity, in the computer; second, that this abandonment of librarianship's traditional focus is reaching an almost frenzied peak of devotion at a time of economic transformation and fiscal shortages that, quite by themselves, may well completely change the role and aspect of institutional libraries of all stripes; and third, that the increasing 'MBA-ization' of senior library administrators everywhere is contributing to a process of cutting libraries off from their rootedness in a broad-based culture, scientific and humanistic, that has nourished them for half a millenium in the West.

Let me assure you that I am not a Luddite and do not regret the presence of the computer in the library. It is a remarkable machine for certain functions; and although, for example, I do sympathize with some of the points made by Nicholson Baker in his now infamous New Yorker article on library catalogues published a couple of years ago ('Annals of Scholarship: Discards,' 4 April I 994: 70, no. 7: 64-70, 72-6, 78-86), I am the first to confess to an admiration for the on-line catalogue at my institution and the almost surreal searching capabilities it possesses. The ESTC is even 
more impressive. As a writer I sold my typewriter several years ago, and even if I do continue for reasons of physical pleasure to write first drafts by hand in a notebook, the advantages of word processing over the typer are obvious and irresistible. So you see that I am not what Arthur and Marielouise Kroker of Concordia University, the gurus of the information society, might call a 'retrotechnophobe.'

What I have watched with alarm is, first of all, the enormous sums of money which have been invested in library technology, almost always defended with the rhetoric of manpower saving and 'increased access,' as though we do not already have too much access and too many people out of work; and secondly, the progress of the myth that access will replace ownership, that a virtual copy, say, of the 1472 Foligno edition of the Divine Comedy will forever make it unnecessary for any library to buy a copy of the book, or to worry about preserving its copy if it already has one. I was once asked by one of the 'computerasts' in my library why, now that a certain book was available on the Internet, we would want or need to have the real thing in the Rare Book Department, just as I was once asked by another colleague why we were keeping the preConfederation pamphlets which he had noticed coming back from being filmed by the Canadian Institute for Historical Microreproduction. These rustically Platonic views of what constitutes research material are no longer a minority opinion. Their purveyors will not end up as rare book curators, of course; but they have a good chance of ending up as the bosses of rare book curators, and I am fearful for the day that happens.

Terry Belanger, in the afterword to The Book Encompassed, a collection issued in 1992 to mark the one-hundredth anniversary of the founding of The Bibliographical Society in England, sees a revolution coming in the world of institutional rare book collections, a revolutionary dismantling of collections and dispersal of books more far-reaching than anything since the Napoleonic era. The onward rush toward downsizing in the higher education sector in Canada which is being overseen and demanded by politicians of every stripe - the Liberals in Ottawa, the Tories in Ontario and Alberta, the Péquistes in Quebec City and so on - is bound to affect the humanities more than the other faculties within the universities, if McGill is any measure. The lawyers, the doctors, and the scientists have a kind of respect and clout that will help them to weather the storm; these are the disciplines which are by definition largely ahistorical and whose research is far less dependent on books, for one thing, than humanities research, and infinitely more 
likely to produce practical applications for another. Think how pervasive has become the vocabulary of neo-conservative business thinking - accountability, profitability, global economy, everything reduced to its financial implications and little else - and now think of the traditional strengths of humanistic research, and you begin to understand that old books may become as endangered as the tropical rain forest. The University of Québec at Montreal is slowly selling off its rare book collection; Metro Toronto Central Library is rumoured to be looking to sell its Audubon Birds of America, a copy brought to Toronto by Audubon himself and sold to William Allan, from whose estate it was bought by Toronto Public Library in 1902 for $\$ 1,900.00$; the University of British Columbia went for several years without a Special Collections Librarian. And these facts represent, I am sure of it, only the preliminary skirmishes in an approaching battle that will see other, equally discouraging casualties.

As far as one can guess, the new university in Canada is likely to be very different from the sort of university I grew up with and have been associated with for the past twenty-five years as either a student or an employee. It will be smaller, it will cost its students a great deal more to attend, and its research focus will be angled much more flagrantly toward profitable enterprises than towards the traditional disinterested search for truth. Its senior administrators will increasingly be drawn from the business sector rather than from the professoriate, and faculties and departments will have to attract much of their own money or face extinction. With fewer faculty to teach, pedagogy will become more and more dependent on the computer in various ways, and as more money is put into automation (as endless a sinkhole for money as libraries ever were), library budgets will continue to shrink, even as the number of books published goes on rising along with their cost. This will make the attraction of selling off parts of the retrospective collection ever more irresistible, a course of action which will be defended by recourse to what I now call the reasoning of the 'Internitwits': it's all there in cyberspace, so why keep the real thing?

I was struck recently in reading a report from McGill University's Planning and Priorities Sub-Committee of the Academic Policy and Planning Committee, a very powerful committee of the University Senate, by the prevalance of the business vocabulary used in describing McGill's current and future academic and financial situation. Words and phrases like 'economically sustainable,' 'shortterm economic benefit,' 'a diverse portfolio of individual research 
projects,' 'competitive,' 'optimize our investments,' 'commercially applicable research,' even 'the academic enterprise,' among others, bespeak a mind-set far, far from that which predominated during my institution's first 175 years, and it says something that the term 'higher learning' now has a curious and vaguely deplorable antiquarian ring to it.

Let me pause here to indulge myself in a brief description of three of the books in the collection at McGill which best represent, to my way of thinking, the characteristics of a rare book collection which surrogates simply cannot equal or replace. I know that all of you who work with antiquarian books and manuscripts could easily furnish a similar list from your own collections. I begin with a copy - beautifully fresh and in the original medium blue paper boards and labels - of a three-volume novel entitled Glenarvon, issued anonymously in 1816 by the London publisher Henry Colburn. It is a scarce work - Sadleir did not own a copy, and Robert Lee Wolff's copy was rebound and lacked the half-titles, the blanks, and the advertisement leaf in volume 3-and as you may know, its author is Lady Caroline Lamb. It is a roman à clef about Byron, Lady Caroline, her family, and some members of Lady Melbourne's circle, and it was written mainly in revenge after Byron married Annabella Milbanke on the second of January, I8I5. 'Is a woman in low spirits?,' Hannah More once wrote. 'Let her console herself by writing a novel.' And so Lady Caroline Lamb did, to the distress of many members of the Regency's highest circles. I cite this example not because of its condition or rarity, however, but because the McGill copy bears the bookplate of William Wilberforce, the evangelical politician through whose efforts the slave trade was abolished in Britain in $\mathbf{1} 807$. Glenarvon is not perhaps a book which we would associate with the saintly Wilberforce, and it is exactly for that reason that this copy is instructive and evocative. To handle it is to establish briefly a direct line to a particular place and time in all their complexities: Byron and Wilberforce, we understand in looking at this novel, inhabited the same world, if not exactly the same sensibility, and the books they bought often looked just like this copy of this novel.

My second example is a copy of an incunable edition of PseudoAugustine, Sermones ad heremitas, published without date in Strassburg by Johann Pruss. Most authorities date the book as not after I488. Our copy is in a monastic binding of quarter pigskin wood and boards, and it came to McGill in the I920s as the gift of Cleveland Morgan, who bought it from Leighton in London, who 
had it from the well-known collection of George Dunn of Woolley Hall. The most interesting feature of this copy, however, is the contemporary buyer's note on the rear pastedown, which reads as follows: 'paulus murator[us] mit [hunc?] libru[m] [?] gross[chen] anno lxxxvii,' which translates as 'Paul Muratorus bought this book for [?] grosschen in the year $87,{ }^{\prime}$ i.e. I487. This note does not allow us to date the edition exactly, but it does at least push the 'not after' date back by one year, and 1487 may well be the correct year of issue. Furthermore, Paulus wrote his Christian name in red ink on the verso of the title-leaf, and there is little question that the modest rubrification throughout this copy is in the same hand and was done by him, a demonstration of the fact that individual owners of early printed books sometimes did their own decorations rather than commissioning a professional flourisher to do the job. Paulus's work consists merely in touching with a little red ink virtually every upper-case letter in the text, as well as adding the initial capitals needed at the beginning of each sermon following the guide letters. ${ }^{\dagger}$

Lastly, and perhaps closest to home for this Society, is a copy of A.M. Klein's first book, Poems, which Klein inscribed for F.R. Scott with the words 'For Frank Scott I With hosannas for his politics I and hallelujahs for his art' and dated 8 February 1945. This is not just an association copy of a book by an important writer who did not often inscribe his books; it is a book which connects two of Montreal's most talented modernist poets who also shared strong political instincts and who were, moreover, students together at McGill and co-founders of the important little magazine the McGill Fortnightly Review in the 1920 .

Books like these do not represent merely bibliophilic icing on the bibliographical cake. They demonstrate some of the unique characteristics which books in individual copies frequently embody, characteristics which facsimiles of any kind naturally eliminate. As such they are rich potential research material, and it would be folly and mania to ignore or to get rid of them simply because the Klein corpus is available in a scholarly edition from the University of Toronto Press, or because Sir Charles Chadwyck-Healey has issued the Patrologia Latina as a searchable database.

Who, then, you will be asking, are the barbarians? I will answer this question, as you expect me to; but let me return for a moment to the Cavafy poem from which I borrowed my title. Cavafy brings his poem to a conclusion with a surprising irony, for the barbarians

† I am grateful to Martin Davies for drawing my attention to this book. 
do not actually show up, and the reaction of those who were waiting for them is not relief, as we might expect, but rather disappointment. Why? Because, as the poet says, the barbarians were a solution, rather than a problem - a solution, I suppose, to history in a sense, or at least to the specific historical problem of what a society is to do when it appears to have come to the end of a cycle in its natural life, even to the end of its natural life altogether. Change by main force is perhaps easier in some ways to accept than the responsibility for deciding one's own future. Cavafy's group of civilized men and women, left to themselves at the end of the poem, must solve their own problems.

For me, then, the barbarians are, first, the 'internitwits' who do not possess a developed and complex understanding for how good research works, and, second, the new corps of academic and library administrators who, having lost touch with the traditional strengths and raison d'être of research libraries, have become mesmerized by the bright light of technology. These two groups together represent the apparent leaders of the academic library world and the formulators of our collective future. They are unlikely to be kind to us and to the collections of old books and manuscripts that we look after. We always need more money, more space, and more staff, and it is these three things - already in short supply which are certain to become rarer than a copy of the Jacques Cartier Bref récit of $\mathrm{I} 545$.

But I have to add a third class of barbarians to the other two, in a reversal which parallels both the Cavafy poem and the novel by J.M. Coetzee which shares its and my title. This third class, I am afraid, is ourselves - not because we share the blinkered world-view of our less bookish colleagues, but because we have failed, miserably at times, to explain and to justify our role in the processes of education and research. We have too often turned our collections into museums, where objects may be seen but not touched. We look down on, when we do not refuse to admit, high school students and undergraduates. We compete fiercely with each other instead of building collections co-operatively. We are wont to babble incomprehensibly about our subject with colleagues who do not share our passion for bibliophily, the book trade, the intricacies of analytical bibliography, and so on. We are given to boasting of the rarities and the high spots in our care, as though the more PMM books we have the better the collection. We do not lament the fact that what we do often has too little administrative relation to what is done in the rest of the library or library system of which we are a part. 
For rare book collections to survive in the evolving higher education ecology - and for people, like bibliographers, who use them also to survive - we must do a far better job of demonstrating, tangibly and visibly, the importance of books in research and teaching, to say nothing of their importance in cultural history construed in its broadest sense. The rapidly growing interest in the history of the book is a good sign and potentially a blessing to bibliographers and rare book curators everywhere. We must ensure that our bosses are kept aware of such developments, even as we must encourage our academic colleagues to take up the cudgels for l'histoire du livre.

R. Howard Block, in a recent book called God's Plagiarist (I994) about Jacques-Paul Migne, the publisher of the Patrologia Latina and the Patrologia Graeca among other sets of books, quotes a remark of Migne which he borrowed from Tertullian and used in many of his sales prospectuses: 'In this world anxious for Progress, we offer the Tradition of the past in order to march forward.' Perhaps it is in a seemingly paradoxical formulation of this kind that the continuing importance of rare book collections can be expressed. We as curators and bibliographers - the developers and the users of such collections - too often take the value of our books to be self-evident. That complacency must evolve, however, if we and the books are to survive. The old technology of the book and the new technology of the computer clearly can co-exist, just as manuscripts continued and continue even now to co-exist with printed books. If at times we seem, like Tertullian himself, to be on the brink of a dark age for learning, then we must renew and expand our efforts to remind our administrators and our users of the centrality and irreplaceability of the book. By those efforts we shall live or not live. Let us hope that in A.D. 2046 my counterpart at the Bibliographical Society of Canada's one-hundredth anniversary dinner will be able to reflect on my talk this evening and wonder why on earth I could have been so gloomy about the future of books. 
RÉSUMÉ

Les bibliothèques d'universités et de recherche ont beaucoup changé durant les dernières décennies. La technologie joue un rôle considérable dans la recherche de l'information. Dans l'espoir d'améliorer l'accès à l'information et d'économiser sur la main d'oeuvre, des sommes d'argent considérables sont dépensées pour le développement de la technologie en bibliothèque. La disponibilité de livres sur microformes et sur l'Internet ont porté certaines personnes à croire qu'on pouvait se passer des livres dans leur format original. De plus, au lieu d'être perçues comme des institutions de haut savoir, les universités sont souvent dirigées comme des corporations. En conséquence, les administrateurs d'universités et de bibliothèques sont choisis non pas à cause de leur expérience et de leur connaissance de la recherche mais pour leur habileté à planifier des budgets et pour leur expertise dans les systèmes informatiques. Pour que les collections de livres rares survivent dans ce monde technologique en constante évolution, les bibliographes et les conservateurs de livres rares doivent constamment rappeler aux administrateurs que le livre et l'ordinateur peuvent coexister et que le livre occupe une place de premier choix dans la mission culturelle de l'université dans les domaines de la recherche et de l'enseignement. 
